\title{
A közel-keleti konfliktusokban tapasztalt drónproliferáció eszkalációs kockázata ${ }^{1}$
}

\begin{abstract}
A 2019-es év során jelentősen megnövekedett azoknak a katonai müveleteknek a száma a közel-keleti konfliktusokban, amelyekben a drónok töltötték be a központi szerepet. Különösen látványos példája volt ennek a 2019. szeptember 14-ei támadás, amelynek során jemeni húszik - feltehetőleg iráni támogatással - mértek csapást szaúdi olajlétesítményekre. Az elemzés rámutat arra, hogy a fokozódó számú közelkeleti drónincidensek növelik a közvetlen katonai összetüzések lehetőségét, illetve ezzel együtt a véletlenszerü és nem szándékolt eszkaláció esélyét is. A rendelkezésre álló adatok alapján úgy tünik, hogy a drónok használata csökkenti a harcászati szintü kockázatot, ugyanakkor növeli a hadászati szintüt.
\end{abstract}

Kulcsszavak: Közel-Kelet, drón, proliferáció, konfliktus, eszkaláció, fegyverkezés

\section{Etl Alex - Pénzváltó Nikolett: The risks of inadvertent escalation of drone incidents in the Middle Eastern conflicts}

\begin{abstract}
The number of military operations in the Middle East in which drones played a central role has significantly increased in 2019. A particularly remarkable example of this was the September 14, 2019 attack in which Yemen's Houthi rebels - most likely with Iranian support - carried out strikes on Saudi oil installations. The analysis highlights that the growing number of drone incidents in the Middle East increases the possibility of a direct military confrontation and the chance of accidental and inadvertent escalation. Based on the available data, it seems that the use of drones reduces the risks at the tactical level while increases it at the strategic level.
\end{abstract}

Keywords: Middle East, drone, proliferation, conflict, escalation, arms race

\section{Bevezetés}

A 2019-es év során jelentősen megnövekedett a drónokat érintő katonai müveletek száma a közel-keleti konfliktusokban. Ezek nyomán elemzésünkben az állami szereplők által a Közel-Kelet térségében végrehajtott dróntámadásokat és ezek eszkalációs potenciálját vizsgáljuk. ${ }^{2}$ Az elemzés első felében a drónok harctéri alkalmazásának előnyeit és eszkalációs potenciálját összegezzük, majd ezt követően az állami szereplőket érintő dróntámadásokat tekintjük át a Közel-Kelet térségére fókuszálva.

\footnotetext{
A szerzők köszönetüket fejezik ki Péczeli Annának szakmai észrevételeiért.

Csak érintőlegesen foglalkozik tehát a nem állami szereplők, köztük különböző terrorszervezetek által elkövetett dróntámadások kockázataival.
} 


\section{A drónok harctéri alkalmazásának előnyei és kockázatai}

A pilóta nélküli repülőeszközök (UAV-k), vagy hétköznapi szóhasználatban drónok legnagyobb alkalmazásbeli előnye kézenfekvően éppen a pilótanélküliségük. Ez több ponton jelent előnyt. Egyrészt hosszabb ideig (akár több mint 24 óráig) képesek folyamatosan a levegőben maradni, hiszen használatuk során nincsenek jelen az emberi fizikai szükségletek mint korlátozó tényezők. Másrészt a pilótafülke helyére „hasznos terhek” (különböző fegyverek) tehetők. Harmadrészt az irányítószemélyzet nincs közvetlen veszélynek kitéve a művelet végrehajtása során, így a drónok alkalmazása csökkenti az elsődleges kockázatot a támadó fél szempontjából. Mivel a pilóta nélküli eszközök alkalmazásakor az adott ország politikai vezetése közvetlenül nem kockáztatja saját embereinek életét, emiatt az esetleges sikertelen kimenetelű műveletekből fakadó politikai (emberi veszteség kommunikációja a választópolgároknak) és a tényleges (kiképzési) költségek is jelentősen alacsonyabbak. ${ }^{3}$

Ezek a jellemzők magyarázzák a drónok széles körü elterjedését a felkelés elleni müveletekben, amelyek sokáig a harci drónok alkalmazásának elsődleges terepét jelentették. Számos alkalommal alkalmazták ezeket az eszközöket (elsősorban nyugati országok) célzott támadások végrehajtására, többek között Afganisztánban, Pakisztánban, Irakban, Líbiában, Jemenben és Szíriában. A felkelés elleni müveletek során általánosan elterjedt értelmezés szerint, mivel nem kell (vagy csak korlátozottan szükséges) szárazföldi erőket telepíteni a fegyveres konfliktus által sújtott térségbe, ezáltal elkerülhetők (vagy csökkenthetők) az emberi veszteségek.

A drónok relatíve könnyelmü használatához egyes szereplők részéröl hozzájárul egy további tulajdonságuk, ez pedig az alkalmazás potenciális tagadhatósága. Különösen nehéz a házilag elöállított vagy kereskedelmi forgalomban megvásárolt és módosított, improvizált drónok által végrehajtott támadások elkövetőjének azonosítása. A drónok ugyanis a ballisztikus rakétáknál jóval alacsonyabb magasságban képesek repülni, ezáltal pedig a radarok és hagyományos légvédelmi rendszerek számára sok esetben láthatatlanok. ${ }^{4}$ Még tovább bonyolítható a visszakövetési lánc, ha az állami szereplők úgynevezett helyettesítő erőket (proxy) alkalmaznak a dróntámadások kivitelezésére. Bár a két támadási forma számos szempontból nem összehasonlítható, a dróntámadások mégis a kibertámadásokhoz hasonló „szürke zónában” mozognak a visszakövethetőség-letagadhatóság és a háború-béke közötti küszöb kérdésének tekintetében. Az államközi konfliktusok során, pilótanélküli repülöeszközökkel végrehajtott csapásokat elemezve úgy tünik, hogy e támadási forma egyfajta átmenetet jelent a hagyományos háborús müveletek és a háborús küszöb alatti müveletek között, hiszen bár jellegét tekintve fizikai erőszakot alkalmaz, ugyanakkor ennek mértéke rendszerint korlátozott marad. A gyakorlatban kivitelezett támadások alapján az eszközök - technológiai sajátosságaik miatt - kiválóan használhatók az aszimmetrikus konfliktusokban, a katonailag gyengébb fél általi csapásmérésekre. Mivel a visszakövethetőség nehézségei lehetőséget biztosítanak a támadó részéről a potenciális tagadhatóságra,

Amy Zegart: Cheap fights, credible threats: The future of armed drones and coercion, The Journal of Strategic Studies, 43. évf. 2020/1, 6-46. o.

4 Stephen Kalin - Sylvia Westall: Costly Saudi defenses prove no match for drones, cruise missiles, [online], 2019. 09. 17. Forrás: reuters.com. E tekintetben a drónok nagyon hasonlóak a robotrepülőgépekhez (cruise missile). 
így a drónok alkalmazása diplomáciai és politikai szempontból tovább növeli a döntéshozók eszköztárát, illetve mozgásterét egy konfliktus eszkalációs skáláján. A Center for Strategic and International Studies (CSIS) tanulmánya egyenesen úgy fogalmaz, hogy a dróntámadások egy új fokot jelentenek az eszkalációs létrán. ${ }^{5}$

Mindez ugyanakkor nem jelenti azt, hogy a dróntámadások ne hordoznának magukban eszkalációs kockázatot. Mivel a drónok alkalmazása a támadó részéről közvetlenül nem veszélyeztet emberéletet, és ezáltal kisebb politikai kockázatot is jelent, így a támadó fél könnyebben dönthet az alkalmazás mellett. Ezáltal a drónok használata közvetett módon a fegyveres konfliktusokra való hajlandóságot növeli, hiszen látszólag csökkenti az azzal járó közvetlen kockázatot. ${ }^{6}$ Ahogy például a Center for New American Security 2015ben, katonákkal, szakértőkkel és döntéshozókkal elvégzett csoportszimulációja rámutatott: a drónok csökkentették a harcászati szintű kockázatot, azonban növelték a hadászati szintüt, mivel az egyes aktorok bátrabban vállalták fel azokat a döntéseket és műveleteket, amelyeket túl kockázatosnak ítéltek volna, ha csak hagyományos repülőgépek álltak volna a rendelkezésükre. ${ }^{7}$ Erre a problémára világított rá a CSIS kutatása is, amelynek során amerikai katonai és politikai döntéshozókkal és szakértőkkel folytatott beszélgetések alapján próbálták megállapítani, hogy hogyan reagálna az Amerikai Egyesült Államok (a továbbiakban: Egyesült Államok) egy drónincidens esetén. ${ }^{8}$ A CSIS elemzése szerint bár papíron egy drón hasonló képességekkel rendelkezik, mint egy hagyományos vadászrepülőgép, ugyanakkor a döntéshozók kevésbé látják offenzívnak egy drón használatát, és ezáltal sokkal inkább hajlandók azt alkalmazni, akár fokozottan veszélyes környezetben is. ${ }^{9}$ A nagyobb telepítési hajlandóság pedig értelemszerűen növeli a direkt összetüzések és a véletlen balesetek/ félreértések számát. ${ }^{10}$ Különösen jelentős problémát okozhat ez olyan konfliktuszónákban, ahol a dróntámadásokra adott megtorló csapások hamar robbanásszerü eszkalációhoz vezethetnek.

A helyzetet tovább bonyolítja, hogy a pilóta nélküli eszközökkel végrehajtott csapások esetére vonatkozó műveletvégrehajtási szabályok (Rules of engagement) egyelőre nem tisztázódtak, ami az aktorok közötti félreértések lehetőségét növeli. Mivel a dróntámadások meglehetősen új jelenségnek számítanak a nemzetközi kapcsolatokban, így nehéz arra következtetni, hogy milyen válaszreakciókat váltanak ki a védelem részéről. A rendelkezésre álló adatok és tapasztalatok alapján úgy tünik, hogy a katonai vezetők és politikai döntéshozók különbséget tesznek a hagyományos repülögépekkel és drónokkal végrehajtott támadások között, ám az nem egyértelmü, hogy mindez mit jelent a gyakorlatban. A korábbiakban már idézett CSIS-kutatás kitér arra is, hogy bár a dróntámadások alapjaiban változtatják meg a támadó fél percepcióját, ugyanakkor a védelem továbbra is a legrosszabb forgatókönyvre készül (csakúgy, mintha hagyományos repülőgép támadná).

\footnotetext{
John Schaus - Kaitlyn Johnson: Unmanned Aerial Systems' Influences on Conflict Escalation Dynamics, [online], 2018. 08. 02, 4. o. Forrás: csis.org [2019. 09. 23.]

6 Michael C. Horowitz - Sarah E. Kreps - Matthew Fuhrmann: Separating Fact from Fiction in the Debate over Drone Proliferation, International Security, 41. évf., 2016/2, 27. o.

Alexandra SANDER: Game of Drones - Wargame Report, [online], 2016. 06. 29. Forrás: drone.cnas.org [2019. 09. 24.]

SCHAUS-JOHNSON: $i$. $m$.

Uo., 6.

10 Horowitz et. al.: $i$. $m$.
} 
Ráadásul, mivel a védelem szempontjából kihívást jelent meghatározni a drón pontos célját és fegyverzetét, valamint - szemben a hagyományos repülögépekkel - a drónokkal történő kommunikáció és a velük szembeni erődemonstráció is nehezebb, így jelentősen leszükül a dróntámadás elrettentésére használható eszközök száma, és megnövekszik az esély a fizikai erőszak alkalmazására a védelem részéről is. Így például a CSIS által megkérdezettek szerint sokkal nagyobb az esélye egy haditengerészeti müvelet esetén a potenciálisan fenyegetést jelentő drón lelövésének, mint annak, hogy egy hagyományos repülőgép váltson ki hasonló reakciót. ${ }^{11}$ Mindeközben az is látható, hogy bár egy drón lelövése is meglehetősen provokatív cselekedetnek számít, ugyanakkor az eredetileg támadó fél részéről nem feltétlenül váltja ki azt a megtorló intézkedést, mintha egy pilóta által vezetett repülőgépét érte volna támadás. ${ }^{12}$

Összegezve tehát a drónok megváltoztatják a támadó fél percepcióját a művelettel kapcsolatban, ezáltal növelik a telepítési hajlandóságot, ugyanakkor befolyásolják a védelem percepcióját is, és növelik a lelövés esélyét. Az ENSZ Leszerelési Kutatóintézetének (UNIDIR) tanulmánya ebből kiindulva három potenciális eszkalációs forgatókönyvet vázol fel. Az első ezek közül a véletlenszerü eszkaláció lehetősége. ${ }^{13}$ Mivel az államok hajlandóbbak a drónok alkalmazására és kevésbé korlátozzák magukat, ezáltal megnő a balesetek (például eltévesztett célpontok, civil áldozatok, technikai problémák stb.) száma, ami hozzájárulhat a véletlenszerü eszkalációhoz, ha az incidens a védelem számára különösen nagy károkat okoz. A második forgatókönyv a nem szándékolt eszkaláció, amelynek keretében a támadó nem számít eszkalációra, és nem várt megtorlócsapást idéz elő a védelem részéről. Ennek egyik oka lehet, hogy ha a védelem le is lövi a támadó drónt, úgy érezheti, hogy nem okozott elégséges és a támadással arányos károkat, ezáltal pedig válaszcsapásra szánja el magát. ${ }^{14}$ A harmadik forgatókönyv pedig a szándékos eszkaláció, ami lényegében a korábbiakban már bemutatott elemekre épül. Mivel a drónok alkalmazása kevésbé költséges és kockázatos, ezért a támadó fél számára kézenfekvő eszköz lehet az erődemonstrációra és a szándékos konfliktuseszkalációra is. ${ }^{15}$ Ezzel együtt az ilyen, meglepetésszerü támadásoktól való félelem a védelmet megelőző csapásokra ösztönözheti. ${ }^{16}$

\section{Állami szereplőket érintő dróntámadások a Közel-Keleten}

Az elmúlt időszakban rendkívüli mértékben felgyorsult a drónok proliferációja a KözelKeleten, ami egyértelmüen hatással van a térség biztonságára. A régióban zajló konfliktusok pedig olyan terepet biztosítanak, ahol komplex viszonyok, harctéri körülmények között alkalmazzák és fejlesztik ezeket az eszközöket. Míg korábban mindössze néhány állam (Egyesült Államok, Izrael és az Egyesült Királyság) rendelkezett fegyverek hordozására, ezáltal katonai csapásmérésre alkalmas harci drónokkal, a térség államai közül rövidesen

\footnotetext{
11 Schaus-Johnson: i. m. 7.

12 Uo., 5.

13 George Woodhams - John Borrie: Armed UAVs in conflict escalation and inter-State crisis, [online], 2018. Forrás: unidir.org [2019. 09. 23.]

14 Uo., 11.

15 Uo., 12.

16 Uo.
} 
felzárkózott hozzájuk Irán és Törökország az első saját fejlesztésű fegyveres drónjaikkal. A legtöbb térségbeli ország, amely nem volt képes a hazai előállításra - és mivel az Egyesült Államok szigorú exportszabályozása és/vagy az amerikai eszközök magasabb költségvonzata miatt nem tudott amerikai drónokat vásárolni - Kínához fordult. Kínai harci drónokkal rendelkezik ma a Közel-Keleten az Egyesült Arab Emírségek, Irak, Szaúd-Arábia, Jordánia, Egyiptom és Algéria is.

A Royal United Services Institute (RUSI) 2018. decemberi összegzése szerint a következő közel-keleti országok rendelkeztek fegyverek hordozására alkalmas pilóta nélküli repülőeszközökkel (1. táblázat):

\section{1. táblázat: Harci drónok a Közel-Keleten}

\begin{tabular}{|c|c|c|}
\hline Ország & $\begin{array}{c}\text { Eszköz neve és darabszáma } \\
\text { (félkövérrel szedve a saját gyártmány) }\end{array}$ & Eddigi földrajzi alkalmazási területek \\
\hline Törökország & $\begin{array}{c}46 \text { db Bayraktar TB2, } \\
6 \text { db Anka-S, } \\
2 \text { db Karayel-SU }\end{array}$ & Törökország, Irak, Szíria, Líbia \\
\hline Irak & 4 db CH-4B Rainbow (kínai) & Irak \\
\hline $\begin{array}{l}\text { Egyesült Arab } \\
\text { Emírségek }\end{array}$ & $\begin{array}{c}5 \text { db Wing Loong, } \\
5 \text { db Wing Loong II. (kínai) }\end{array}$ & Jemen, Líbia \\
\hline Szaúd-Arábia & $\begin{array}{l}2 \mathrm{db} \text { CH-4B Rainbow, } \\
5 \mathrm{db} \text { Wing Loong II. }\end{array}$ & - \\
\hline Irán & $\begin{array}{l}5-10 \mathrm{db} \text { Mohajer-6, } \\
24-40 \mathrm{db} \text { Shahed-129 }\end{array}$ & $\begin{array}{l}\text { Szíria, Irak (illetve a proxy erők, mint } \\
\text { a Hamász, Hezbollah, Anszár Allah által } \\
\text { végrehajtott támadások) }\end{array}$ \\
\hline Izrael & $\begin{array}{c}10-15 \mathrm{db} \text { Heron TP, } \\
20-30 \mathrm{db} \text { Hermes 450, } \\
10-15 \mathrm{db} \text { Hermes } 900\end{array}$ & $\begin{array}{c}\text { Gázai övezet, Libanon, Egyiptom, Szíria, } \\
\text { Szudán }\end{array}$ \\
\hline Jordánia & $2 \mathrm{db} \mathrm{CH}-4 \mathrm{~B}$ Rainbow & - \\
\hline
\end{tabular}

Forrás: Armed Drones in the Middle East, [online], 2018. Forrás: drones.rusi.org [2019. 09. 23.]

Ezenfelül sajtóhírekből tudható, hogy azóta Egyiptom (Wing Loong) és Algéria (CH-4B) is rendelkezik csapásmérésre alkalmas kínai drónokkal. ${ }^{17}$ A 2019-es Military Balance szerint hírszerzési, megfigyelési és felderítési (ISR-) műveletekben alkalmazható drónja van továbbá Marokkónak (amerikai Skyeye), Libanonnak (iráni Mohajer 4) és Szíriának (iráni Mohajer és Ababil). ${ }^{18}$

A 2018-as évtől kezdődően érzékelhetően megnövekedett a közel-keleti dróntámadásokról tudósító híradások száma. 2018. január 5-6-án például az első feljegyzett, rajban elkövetett (swarm) dróntámadást hajtották végre Szíriában orosz bázisok ellen. A hivatalos orosz közlemény szerint 13 eszköz követte el az összehangolt támadást (amelyböl 10 Khmeimim, 3 pedig Tartúsz bázisa felé haladt), az orosz légvédelemnek köszönhetően azonban a támaszpontok nem szenvedtek semmilyen kárt vagy veszteséget. A 13 eszközből

17 Jeremy BinniE: Egypt shows Wing Loong UAV, [online], 2018. 10. 19. Forrás: janes.com [2019. 09. 23.]

18 Chapter seven: Middle East and North Africa, The Military Balance, International Institute for Strategic Studies, London, 119. évf., 2019, 320-379. o. 
hatot elektronikai hadviselés alkalmazásával, hetet pedig az orosz Pancir-Sz légvédelmi rakétarendszerek segítségével semmisítettek meg. ${ }^{19}$ Bár ezt alátámasztó bizonyítékokat nem tudott felmutatni, az orosz retorika nem zárta ki annak lehetőségét, hogy állami szereplő támogatása áll a szíriai felkelők által végrehajtott támadás mögött. ${ }^{20}$ Felmerült az Egyesült Államok esetleges felelőssége is a támadásban, ez azonban nem tekinthető meglepőnek, hiszen a „terroristákat támogató” amerikai állam képe jól illeszkedik a szélesebb orosz narratívába. A Törökország által támogatott szíriai ellenzéki erők által ellenőrzött területről indított támadás a török-orosz normalizációs folyamatot is veszélyeztette, Vlagyimir Putyin orosz elnök azonban kijelentette, hogy nem Ankara felelős a támadásért, és a kétoldalú kapcsolatok bomlasztását célzó provokációnak minősítette az esetet. A példából azonban látható, hogy a nem állami szereplők által végrehajtott dróntámadások államközi kapcsolatokra is jelentős hatást gyakorolhatnak.

Napjaink közel-keleti dróntámadásaiban vitathatatlanul Irán tölti be a központi szerepet. Teherán hatékonyan használja ki a drónokban rejlő lehetőségeket, elsősorban a proxyk használatát és a potenciális tagadhatóság lehetőségét, és egyfajta aszimmetrikus, kemény diplomáciai eszközként használja a dróntámadásokat - eddig elsősorban izraeli és szaúdi célpontok ellen -, illetve demonstrálja a térség destabilizálására való képességét. Nem állíthatjuk azonban, hogy az ilyen típusú támadások új keletűek. Az izraeli légierő első alkalommal 2006-ban találkozott robbanóanyagot szállító iráni gyártmányú drónokkal: a második libanoni háború idején a Hezbollah három Ababil „öngyilkos” drónt indított Izrael felé, amelyeket az izraeli F-16-osoknak sikerült lelöniük. ${ }^{21}$

A drónok növekvő számú alkalmazása azonban növeli az eszkaláció esélyét is. Erre kiváló példát láthattunk 2018 februárjában, amikor az izraeli légierő lelőtt egy Szíria felől az izraeli légtérbe behatoló iráni drónt, ami az izraeli tájékoztatás szerint felfegyverzett volt. Izrael az iráni drón határsértésére válaszul támadást intézett a szíriai Palmüra melletti feltételezett iráni indítóállás ellen, amire válaszul Szíria lelőtt egy izraeli F-16-os repülőgépet. Az eset azért is jelentős, mivel ezt megelőzően legutóbb 1979-ben lőttek le izraeli vadászgépet. Az esetre reagálva Tel-Aviv szíriai és iráni célpontok ellen intézett újabb megtorló csapásokkal válaszolt. ${ }^{22}$ Hasonló megtorló intézkedésekre került sor Izrael részéről 2018 júliusában is, szintén egy Szíriából érkező dróntámadásra válaszul. ${ }^{23}$

A dróntámadásokkal kapcsolatban megnövekedett a jemeni húszik (hivatalos nevükön Anszár Allah) mint iráni helyettesítő erők szerepe is. 2018-tól kezdve a húszik számos - elsősorban drónokkal, robotrepülőgépekkel és rakétákkal végrehajtott - támadást indítottak szaúdi célpontok (repülőterek, kőolaj-infrastruktúra stb.) ellen. ${ }^{24}$ Mindez azt is jól szimbolizálja, hogy a húszik - feltehetőleg iráni segítséggel - képesek voltak rendkívül

19 Az Oroszországi Föderáció Védelmi Minisztériumának (@mod.mil.rus) Facebook-posztja, [online], 2018. 01.08. Forrás: facebook.com [2019. 09. 23.]

20 Uo.

21 Milton Hoenig: Hezbollah and the Use of Drones as a Weapon of Terrorism, Public Interest Report, 67. évf., 2014/2.

22 Maayan Lubell - Lisa BARrington: Israeli jet shot down after bombing Iranian site in Syria, [online], 2018. 02.10. Forrás: reuters.com [2019. 09. 23.]

23 Yaniv Kubovich - Noa Shpigel: Israel Fires at Second Drone Approaching From Syria This Week, [online], 2018.07. 13. Forrás: haaretz.com [2019. 09. 23.]

$24 \mathrm{Az} \mathrm{Al} \mathrm{Jazeera} \mathrm{összegyüjtötte} \mathrm{ezeket} \mathrm{a} \mathrm{támadásokat.} \mathrm{A} \mathrm{részletekért} \mathrm{lásd:} \mathrm{Timeline:} \mathrm{Houthis'} \mathrm{drone} \mathrm{and} \mathrm{missile} \mathrm{attacks} \mathrm{on}$ Saudi targets, [online], 2019. 09. 14. Forrás: aljazeera.com [2019. 09. 23.] 
szofisztikált, összehangolt és célzott támadások kivitelezésére, amelyek elsősorban egy jól átgondolt diplomáciai üzenet értékével bírtak, hiszen rámutattak a szaúdi olajinfrastruktúra sebezhetőségére és Irán aszimmetrikus képességeinek potenciális hatékonyságára. ${ }^{25}$

A legutóbbi és legakutabb ügy a 2019. szeptember 14-ei támadás szaúdi olajlétesítmények ellen, amelynek következményeként átmenetileg több mint a felére csökkent a szaúdi napi kőolaj-kitermelés, így a támadás hatásait a teljes világpiac megérezte. A műveletért a jemeni húszik vállalták a felelősséget, Szaúd-Arábia és az Egyesült Államok azonban Iránt nevezte meg felelősként. A vizsgálat még tart, jelenlegi állása szerint azonban 18 drón és 7 robotrepülőgép érte a létesítményeket „északi irányból”, Jement ezért kizárták azok lehetséges forrásai közül. ${ }^{26}$ A szeptemberi támadás azért is jelentős, hiszen bebizonyította, hogy a korlátozott erőforrásokból létrehozható dróntámadások aszimmetrikus módon, stratégiai hatás kiváltására is képesek. Mindeközben pedig az is látható, hogy a relatíve alacsony költségvonzattal rendelkező támadási forma sikeresen ki tudta játszani a szaúdi haderőt, amely - az Egyesült Államok és Kína után - a világ harmadik legnagyobb védelmi kiadásaival rendelkezik. A 2019. szeptemberi támadásra mind ez idáig nem érkezett direkt válaszcsapás, ám az Egyesült Államok kijelentette, hogy egy újabb Patriot üteget, további 200 katonát és 4 darab, 360 fokos látómezővel rendelkező Sentinel radart küld SzaúdArábiába. $^{27}$

A probléma súlyát és a hagyományos védelmi eszközök tehetetlenségét jól érzékelteti, hogy a megtámadott létesítményeket Patriot légvédelmi rendszerek védték, ugyanakkor ezek képtelenek voltak a müvelet megakadályozására. ${ }^{28}$ Ennek oka az is, hogy a Patriotokat elsősorban nagy magasságban repülő célpontok (ballisztikus rakéták és vadászrepülőgépek) elleni védelem céljából fejlesztették ki, nem a rendkívül alacsonyan repülő drónok és robotrepülőgépek ellen. ${ }^{29}$ Ráadásul a Patriot rakéták 2-3 millió dollár körüli ára nem is lenne arányban a jóval olcsóbban beszerezhetö kereskedelmi drónokkal, így a védelem egyébként is hamar túlterhelhetővé válhatna. ${ }^{30}$ A szaúdi létesítményeket Skyguard tüzvezető rendszerrel ellátott 35 mm-es Oerlikon GDF gépágyúk, illetve Shahine (a francia Crotale egy változata) légvédelmi rakétarendszerek védték, de mivel ezeket a régebbi eszközöket nem drónokkal szemben fejlesztették ki, így nem tudták megakadályozni a támadást. ${ }^{31}$ $\mathrm{Az}$ incidens rámutatott arra is, hogy továbbra is szükség van korszerü, rövid hatótávolságú

25 Micha'el Tanchum: Drone Attacks on Saudi Oil Infrastructure are a Calibrated Message from Iran, IAI Commentaries, 19/35. 2019, 5. o.

26 Rory Jones - Sune Engel Rasmussen: What We Know About the Saudi Oil Attacks, [online], 2019. 09. 20. Forrás: wsj. com [2019. 09. 23.]

27 Missy Ryan - Dan Lamothe: After oil attack, Pentagon authorizes modest air defense boost for Saudi Arabia, [online], 2019. 09. 26. Forrás: washingtonpost.com [2019. 09. 27.]

28 Kalin-Westall: $i$. m.

29 Sebastien Roвlin: Why U.S. Patriot missiles failed to stop drones and cruise missiles attacking Saudi oil sites, [online], 2019. 09. 23. Forrás: nbcnews.com [2019. 09. 23.]

30 A kereskedelmi drónok ára átlagosan néhány száz / néhány ezer USD körül alakul. A Közel-Keleten alkalmazott katonai drónok árával kapcsolatban nincsenek pontos információink. A becslések alapján a népszerü, kínai Wing Loong ára 1-2 millió USD között alakulhat. Forrás: Franz-Stefan GADY: China’s New Killer Drone Conducts Missile Firing Tests, [online], 2018. 01. 03. Forrás: thediplomat.com [2019. 09. 26.]

31 Sebastien Roblin: The Army's ,Big Six': America Plan to Wipe Out Russia or China In a War, [online], 2019. 06.09. Forrás: nationalinterest.org [2019.09. 26.] 
légvédelmi rendszerekre is, amelyek képesek a látótávolságon belüli célpontok megsemmisítésére. Ezt támasztja alá az is, hogy az amerikai haderő a top hat modernizációs prioritásává tette e rendszerek kifejlesztését. ${ }^{32} \mathrm{~A}$ jövőben várhatóan növekvő szerepet kapnak majd a lézer- és elektronikai fegyverek is a drónok elleni védelemben. ${ }^{33}$

A drónok ugyanakkor nemcsak támadóeszközként, hanem potenciális célpontként is egyre gyakrabban jelennek meg a közel-keleti konfliktusokban. Így például 2019 augusztusában Izrael mért csapást több szíriai célpontra, amelyek Tel-Aviv állítása szerint épp egy "gyilkos drónokkal” végrehajtott támadást készítettek elö. ${ }^{34} 2019$. június 20-án Irán lőtt le egy amerikai Global Hawkot a Hormuzi-szoros fölött, amire az Egyesült Államok megtorló kibercsapással válaszolt. Ez utóbbi incidens is jól érzékelteti, hogy az államok bizonyos mértékig különbséget tesznek a drónokat és a hagyományos repülőgépeket ért támadások között, hiszen Washington egy fizikai támadásra végül nem fizikai válaszcsapással reagált. Az esettel kapcsolatban Donald Trump amerikai elnök is úgy nyilatkozott, hogy irániak megölése nem lenne egyensúlyban egy pilótanélküli eszköz lelövésével. ${ }^{35}$

Mindeközben Törökország és az Egyesült Arab Emírségek között pedig lényegében helyettesekkel vívott drónháború zajlik Líbiában. A líbiai Nemzeti Egyetértés Kormánya (GNA) sajtóhírek szerint májustól kezdődően eddig legalább 12 darab Bayraktar TB-2-est kapott Törökországtól, aminek mintegy felét elpusztították az Emírségek Khalífa Haftar tábornok oldalán bevetett Wing Loong II-ei. ${ }^{36} \mathrm{~A}$ líbiai helyzet egy újabb példát szolgáltat a lehetséges eszkalációra. A török Bayraktarokat megfelelően képzett líbiai kezelőszemélyzet hiányában török operátorok üzemeltették, akik közül június 6-án ketten is megsérültek egy támadásban. ${ }^{37}$

\section{Kitekintés}

A közelmúltban végrehajtott támadások tapasztalataiból (és katonai sikereiből) arra következtetünk, hogy a drónok feltehetőleg egyre nagyobb szerephez jutnak majd az államközi konfliktusokban. A pilóta nélküli eszközökkel végrehajtott támadások egyfajta „szürke zónában" mozognak, és átmenetet jelentenek a háborús és nem háborús katonai müveletek között. A Közel-Keleten felgyorsult ütemű drónproliferáció egyértelműen jelzi, hogy a térség államai aktívan számolnak a pilóta nélküli eszközök katonai használatával a jövőben is. Mindeközben a fokozódó számú incidensek növelik a direkt katonai összetüzések gyakoriságát, illetve ezzel együtt a véletlenszerü és nem szándékolt eszkaláció esélyét is.

32 Uo.

33 Uo.

34 David M. Halbfinger: Israel Says It Struck Iranian 'Killer Drones' in Syria, [online], 2019. 08. 24. Forrás: nytimes.com [2019. 09. 23.]

35 Ellen NAKASHIMA - Paul Sonne: U.S. military carried out secret cyberstrike on Iran to prevent it from interfering with shipping, [online], 2019. 08. 28. Forrás: washingtonpost.com [2019. 09. 23.]

36 Arnaud DeLALANDE: How Libya’s skies became battleground for UAE-Turkey proxy war, [online], 2019. 08. 27. Forrás: middleeasteye.net [2019. 09. 23.]

37 Uo. 


\section{FELHASZNÁLT IRODALOM}

Armed Drones in the Middle East, [online], 2018. Forrás: drones.rusi.org [2019. 09. 23.]

Az Oroszországi Föderáció Védelmi Minisztériumának (@mod.mil.rus) Facebook-posztja, [online], 2018. 01. 08. Forrás: facebook.com [2019. 09. 23.]

BINNIE, Jeremy: Egypt shows Wing Loong UAV, [online], 2018. 10. 19. Forrás: janes.com [2019. 09. 23.]

Chapter seven: Middle East and North Africa, The Military Balance, International Institute for Strategic Studies, London, 119. évf., 2019, 320-379. o. DOI: https://doi.org/10.1017/CBO9781316221839.008

Delalande, Arnaud: How Libya’s skies became battleground for UAE-Turkey proxy war, [online], 2019. 08. 27. Forrás: middleeasteye.net [2019. 09. 23.]

Gady, Franz-Stefan: China’s New Killer Drone Conducts Missile Firing Tests, [online], 2018. 01. 03. Forrás: thediplomat.com [2019. 09. 26.]

Halbfinger, David M.: Israel Says It Struck Iranian 'Killer Drones' in Syria, [online], 2019. 08. 24. Forrás: nytimes.com [2019. 09. 23.]

Hoenig, Milton: Hezbollah and the Use of Drones as a Weapon of Terrorism, Public Interest Report, 67. évf., $2014 / 2$.

Horowitz, Michael C. - Kreps, Sarah E. - Matthew Funrmann: Separating Fact from Fiction in the Debate over Drone Proliferation, International Security, 41. évf., 2016/2, 7-42. o. DOI: https://doi.org/10.1162/ ISEC_a_00257

Jones, Rory - Rasmussen, Sune Engel: What We Know About the Saudi Oil Attacks, [online], 2019. 09. 20. Forrás: wsj.com [2019. 09. 23.]

Kalin, Stephen - Westall, Sylvia: Costly Saudi defenses prove no match for drones, cruise missiles, [online], 2019. 09. 17. Forrás: reuters.com. [2019. 09. 23.]

Kubovich, Yaniv - Shpigel, Noa: Israel Fires at Second Drone Approaching From Syria This Week, [online], 2018. 07. 13. Forrás: haaretz.com [2019. 09. 23.]

Lubell, Maayan - BARRINGTon, Lisa: Israeli jet shot down after bombing Iranian site in Syria, [online], 2018. 02. 10. Forrás: reuters.com [2019. 09. 23.]

NAKASHIMA, Ellen - Sonne, Paul: U.S. military carried out secret cyberstrike on Iran to prevent it from interfering with shipping, [online], 2019. 08. 28. Forrás: washingtonpost.com [2019. 09. 23.]

Roblin, Sebastien: The Army's 'Big Six’: America Plan to Wipe Out Russia or China In a War, [online], 2019. 06. 09. Forrás: nationalinterest.org [2019. 09. 26.]

Roblin, Sebastien: Why U.S. Patriot missiles failed to stop drones and cruise missiles attacking Saudi oil sites, [online], 2019. 09. 23. Forrás: nbcnews.com [2019. 09. 23.]

Ryan, Missy - Lamothe, Dan: After oil attack, Pentagon authorizes modest air defense boost for Saudi Arabia, [online], 2019. 09. 26. Forrás: washingtonpost.com [2019. 09. 27.]

SANDER, Alexandra: Game of Drones - Wargame Report, [online], 2016. 06. 29. Forrás: drone.cnas.org [2019. 09. 24.]

Schaus, John - Johnson, Kaitlyn: Unmanned Aerial Systems' Influences on Conflict Escalation Dynamics, [online], 2018. 08. 02. Forrás: csis.org [2019. 09. 23.]

TAnchum, Micha'el: Drone Attacks on Saudi Oil Infrastructure are a Calibrated Message from Iran, IAI Commentaries, 19/35. 2019, 5. o.

Timeline: Houthis' drone and missile attacks on Saudi targets, [online], 2019. 09. 14. Forrás: aljazeera.com [2019. 09. 23.]

Woodhams, George - BorRIE, John: Armed UAVs in conflict escalation and inter-State crisis, [online], 2018. Forrás: unidir.org [2019. 09. 23.]

ZegarT, Amy: Cheap fights, credible threats: The future of armed drones and coercion, The Journal of Strategic Studies, 43. évf. 2020/1, 6-46. o. DOI: https://doi.org/10.1080/01402390.2018.1439747 